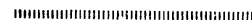

論 文 ORIGINAL PAPERS

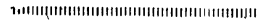

$$
\begin{gathered}
\text { オーステナイト系ステンレス鋼における } \\
\text { 水素化物の } \mathrm{X} \text { 線的研究* }
\end{gathered}
$$

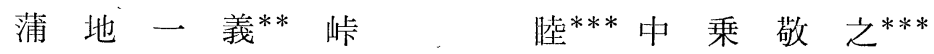

\title{
X-Ray Study of Hydrides in Austenitic Stainless Steels
}

by

\section{Kazuyoshi Kamachi, Mutsumi ToGe and Takayuki NAKANORI}

(Faculty of Engineering, Yamaguchi University, Ube)

Electrolytical charging of hydrogen into austenitic stainless steels induces a phase transformation from austenite to martensite and hydride formation. The behaviours of these phases have been studied by X-ray diffraction analysis.

Hydrides formation was found to be dependent on the nickel content and charged hydrogen concentration in steel. Diffraction analysis of the specimen cathodic-charged at $60^{\circ} \mathrm{C}$ revealed the formation of hydride phases $\left[\varepsilon^{\prime}(c . p . h\right.$.$) and Y_{1}, Y_{2}$ (F.C.C. $\left.)\right]$. The hydride phases were stable at $-78^{\circ} \mathrm{C}$, but as temperature is raised gradually from $-78^{\circ} \mathrm{C}$ to room temperature, they become unstable and the martensitic phases were formed.

The order of the phase transformation by cathodic charge of hydrogen was

in the charging process, and

$$
\left[\gamma \rightarrow \text { hydrides }\left(\varepsilon^{\prime}+Y\right) \rightarrow \alpha_{H}^{\prime} \rightarrow \alpha^{\prime}{ }_{H}+\varepsilon_{H}\right]
$$

in the aging process.

$$
\left[\gamma \rightarrow \text { hydrides }\left(\varepsilon^{\prime}+Y\right) \rightarrow \varepsilon_{H} \rightarrow \varepsilon_{H}+\alpha^{\prime}{ }_{H}\right]
$$

(Received June 21, 1976)

\section{1 緒言}

オーステナイト系ステンレス鋼に陰極電解法によっ

て水素を吸蔵せしめると水素化物が生成し，変態が誘 起されることについて従来報告してきた. Vaughan らは $\alpha^{\prime}$-マルテンサイトと水素化物相を生じるとし， Holtzworth らはこの水素化物相を水素吸藏により誘 起された れーマルテンサイト相と考无た. 岡田ら, 大 谷らによっても相変態についてX線的に研究がなされ
ている.これらの現象はオーステナイトの安定度と関 連がある、したがって合金中の $\mathrm{Ni}$ 量とも密接に関係 する.

本研究では, オーステナイト系ステンレス鋼に重点 を置いて，水素化物相と変態相拈よびそれらの生成過 程と挙動について，X線的に観察を行った. 水素化物

\begin{tabular}{|c|c|c|c|c|c|c|c|c|c|c|}
\hline Material & $\mathrm{C}$ & $\mathrm{Si}$ & $\mathrm{Mn}$ & $\mathrm{P}$ & $\mathrm{S}$ & $\mathrm{Ni}$ & $\mathrm{Cr}$ & Mo & $\mathrm{Cu}$ & Co \\
\hline SUS 304 & 0.06 & 0.55 & 1.09 & 0.027 & 0.013 & 896 & 1831 & 004 & 0.08 & - \\
\hline SUS 316 & 006 & 0.74 & 1.75 & 0.026 & 0.006 & 1291 & 17.39 & 2.48 & 0.22 & - \\
\hline SUS $310 \mathrm{~S}$ & 0043 & 0.92 & 1.53 & 0.024 & 0.008 & 19.24 & 24.58 & - & - & - \\
\hline $\mathrm{Fe}-31 \% \mathrm{Ni}$ & 0.02 & 0.04 & 0.06 & - & - & 30.8 & - & - & 0.11 & 0.44 \\
\hline $\mathrm{Fe}-32 \% \mathrm{Ni}$ & 0.023 & 0.03 & 0.06 & - & - & 32.3 & - & - & - & 0.06 \\
\hline
\end{tabular}
は低温で安定な相であるので，低温試料台によって温 度を変化させてX線回折を行い，その挙動を䛨しく調

Table I. Chemical composition (wt.\%).

* 原稿受理 昭和51年 6 月21日

** 正会 員 山口大学工学部 宁部市常盤台

*** 山口大学工学部 宇部市常盤台 


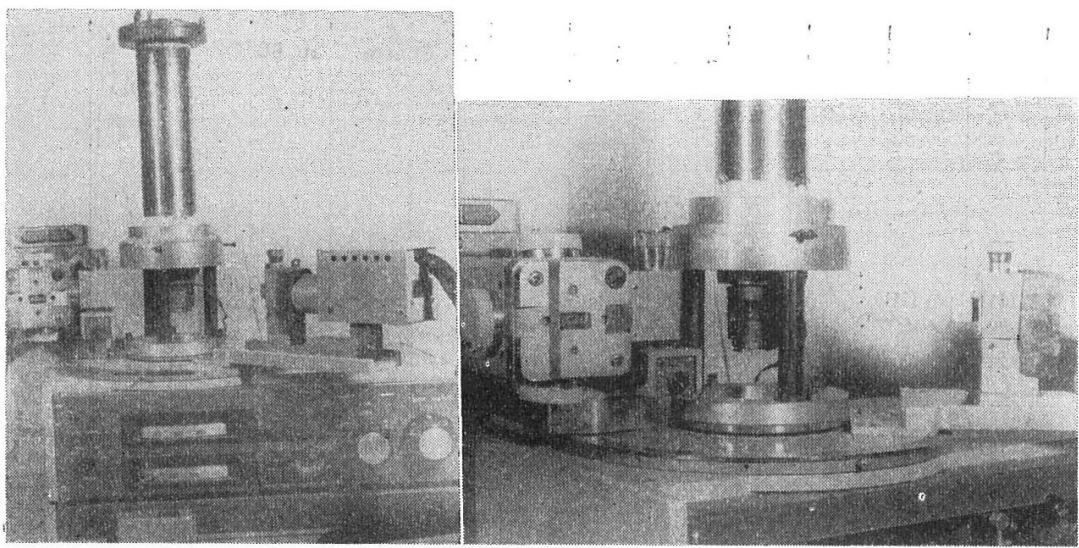

Fig. 1. A cryostat for $\mathrm{X}$-ray diffraction studies.

ベた。

\section{2 供試材および実験方法}

\section{$2 \cdot 1$ 供試材}

供試材はオーステナイト系ステンレス鋼 SUS 304, 316，310S と Fe-31，32\% Ni 合金であって，その組 成を Table I 飞示与。試片は $0.8 \mathrm{~mm}$ 厚とし, 20 $\mathrm{mm} \times 50 \mathrm{~mm}$ の短冊型に切断して用いた．溶体化処理 は $10500^{\circ} \mathrm{C}$ て厚さ $1 \mathrm{~mm}$ につい $10 \mathrm{~min}$ 保持した後 油冷した。表面は電解研摩走施して光沢面とし実験に 供した。

\section{$2 \cdot 2$ 実験方法}

水素吸蔵以陰極電解法により行った。電解液は $\mathrm{As}_{2}$ $\mathrm{O}_{3}$ を $340 \mathrm{mg} / 1$ 加光た 0.1 規定 $\mathrm{H}_{2} \mathrm{SO}_{4}$ 溶液に白金線 陽極老用いた。電流密度は $0.02 \mathrm{Amp} / \mathrm{cm}^{2}$ とした。 また吸蔵温度は $20^{\circ} \mathrm{C} と 60^{\circ} \mathrm{C}$ とた。 $60^{\circ} \mathrm{C}$ で吸蔵すると 水素化物は顕著に生成することから常温の場合と比較 するため行った。

次の二つの目的で低温試料台を作成した。(1)水素吸 蔵された試片の温度を低温に保つことによって水素化 物相を安定させてX線回折を行うこと。(2)徐及に昇温 させて, 水素化物相および変態相の挙動を詳しく観察

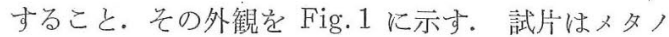
ールとドライアイスを 1:1 で混合したもの，㘯るい は液体窒素によって $-78^{\circ} \mathrm{C} ，-196^{\circ} \mathrm{C}$ 冷却される。 温度は銅ーコンスタンタン熱電対を試料台に埋め込え で，千野製25R型電子式指示記録計により記録した。

X線回折は皂津製自動記録式X線回折装置 $(\mathrm{VD}-2)$ によって, Co ターダット, Feフィルタ支用いて行っ た。管電圧は $30 \mathrm{kVp}$, 管電流は $10 \mathrm{~mA}$ とした。

\section{3 実験結果および考察}

\section{$3 \cdot 1$ 水素化物の生成}

Fig. 2 はSUS 304 について各吸蔵時間ごとの peak の変化を $2 \theta=48^{\circ} \sim 61^{\circ}$ の筙用で示したるのである。 電解液の温度圭 $20^{\circ} \mathrm{C}$ とて $15 \mathrm{~min}$ 吸蔵圭行らと $2 \theta$
SUS $304 \mathrm{H}_{2}$ charge at $20^{\circ} \mathrm{C}$

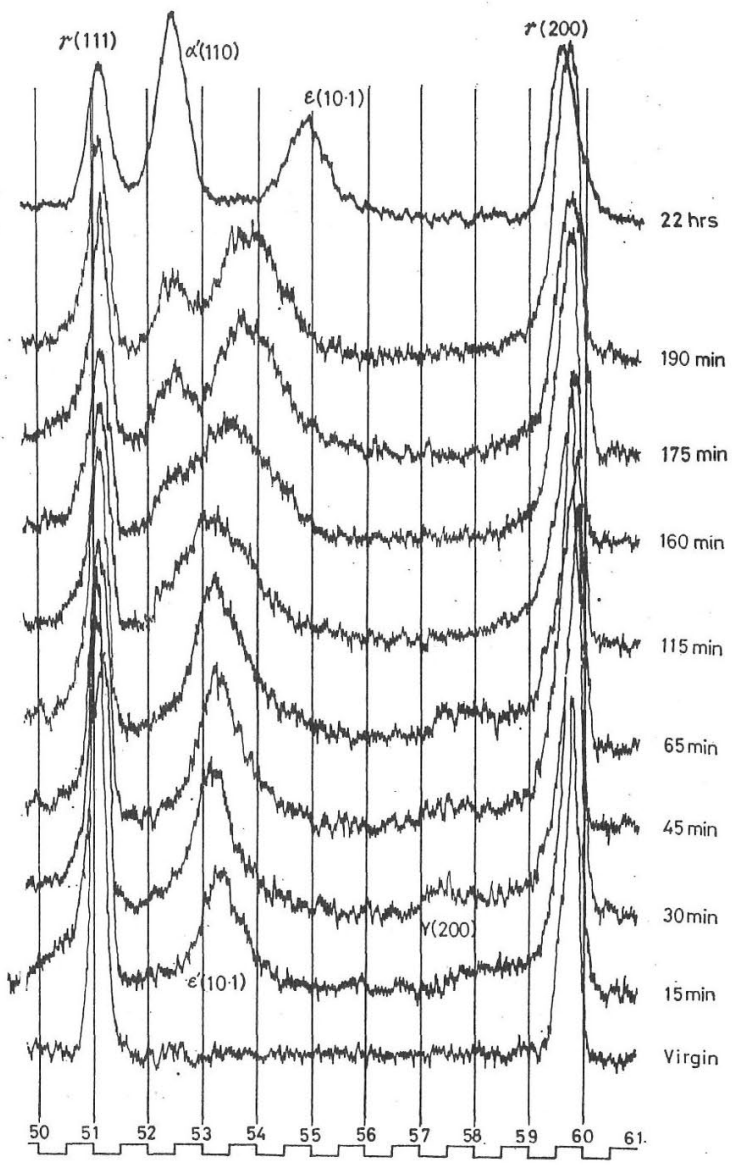

\section{$2 \theta$ (deg.) CoK $\alpha$}

Fig. 2. X-ray diffraction patterns. Effect of hydrogen charge at room temperature. (SUS 304)

$\doteqdot 53^{\circ}$ 付近に新しい peak が現れ，吸蔵時間の増加と 共に气の回折強度が增与ことがわかる。この peak は $a=2.65 \AA, c=4.31 \AA, c / a=1.63$ の h.c.p. 構造 


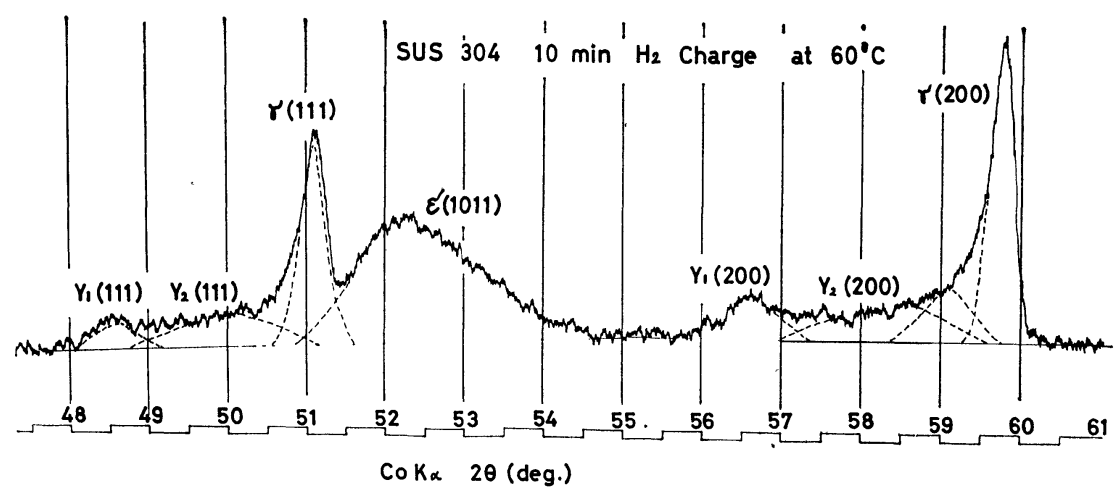

Fig. 3. An $\mathrm{X}$-ray diffraction pattern. Hydride phases produced by cathodic charging at $60^{\circ} \mathrm{C}$. (SUS 304)

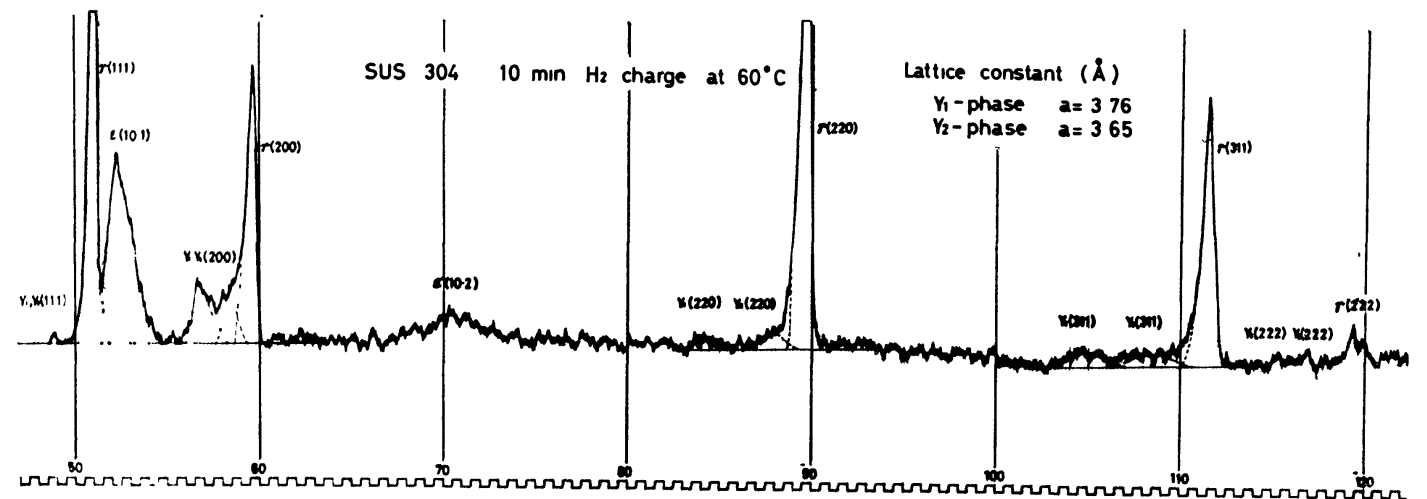

Cokk $2 \theta$ (deg.)

Fig. 4. An X-ray diffraction pattern. Effect of 10 min hydrogen charge at $60^{\circ} \mathrm{C}$. (SUS 304)

とした場合の（10.1）面からの peak と一致する.こ れは水素吸蔵により生成した $\varepsilon$ 相であるので $\varepsilon^{\prime}$ 相 と する.また $\gamma$ 相の低角側に膨みがみられる。この膨み はオーステナイト母相のマトリックスのピーク全体が 低角側にシフトしているのではないことから，母相表 面の薄い層に水素原子が侵入したことによる, 格子の 膨張を示していると思われる。ささらに吸蔵を続けると $2 \theta=50^{\circ}$ および $58^{\circ}$ にわずかな peak が観察され 60 min 吸藏したとき最も顕著となる。この peakを生 ずる生成相をY相と呼ぶ. Y相は $\gamma$ 相の (220), (311), （222）各面にむ随伴し，それぞれ明らかな peak を形 成するるのであって，単なる膨張した母相とは考兄ら れないことから, f.c.c. 格子を有する水素化物相 と 考兄られる. $\varepsilon^{\prime}$ 相招よびY相は水素吸蔵により生成し, 変態相が誘起される以前の段階では吸蔵される水素量 の増加に従って回折強度は強まる. ステンレスは $\mathrm{Fe}$, $\mathrm{Cr}, \mathrm{Ni}$ の固溶態であるのでオーステナイトの 水素化 物 (Hydride) と考学られ.

Fig. 3 はSUS 304 に $60^{\circ} \mathrm{C}$ で $10 \mathrm{~min}$ 水素吸蔵せ乙 めたときのチャートである。 $\varepsilon^{\prime}(10 \cdot 1)$ 面からの peak は非常に大きくブロードである。またY相もはっきり
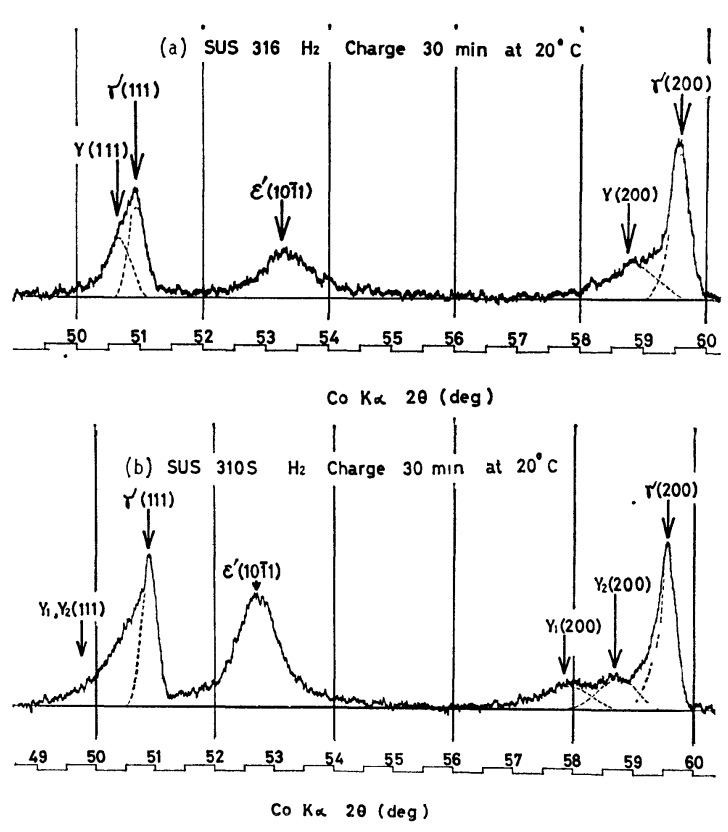

Fig. 5. X-ray diffraction patterns. Effect of 30 min hydrogen charge at room temperature. (a) SUS 316 (b) SUS $310 \mathrm{~S}$ 
認められる. 高温では多量の水素が吸蔵されると考え られ，Y相は二種類生成した.このとき格子定数の大 きい方を $\mathrm{Y}_{1}$ 相，小さい方を $\mathrm{Y}_{2}$ 相とした. Fig. 4 は 全角チャートであるが, オーステナイトの各面の peak に随伴してY相が現れることがよくわかる.これより 求めた格子定数は $\mathrm{Y}_{1}$ 相が $3.76 \AA, \mathrm{Y}_{2}$ 相が $3.65 \AA$ であった. $\varepsilon^{\prime}$ 相は, $a=2.68 \AA, c=4.18 \AA, c / a=1.56$ となり, $20^{\circ} \mathrm{C}$ 場合より $c / a$ の值が小さくなっている. このよらに水素化物相は吸蔵温度を高くすると, 合金 中の水素溶解量が増加し, 生成が顕著となる.

つぎに Ni 量の異る場合の水素化物の生成の違いを 示した. Fig. 5 (a)は SUS 316 に20で $30 \mathrm{~min}$ 水素 吸蔵を行ったときのチャートである.オーステナイト の peak の低角側の膨文は大きく，とくに $\gamma$ (111) 面 からのpeak はブロードになっている.これはY (111) 面と $\gamma$ (111) 面からの peak が重畳したためである. (b)は SUS 310S に同じ条件で水素を吸蔵せしめたも のであるが, peak はさらにブロードとなっている. $\varepsilon^{\prime}(10 \cdot 1)$ 面からの peak は SUS 316 に比べて回折
強度がかなり大きい。 また $\mathrm{Y}$ 相も $\mathrm{Y}_{1}$ 相と $\mathrm{Y}_{2}$ 相がは っきり区別される.

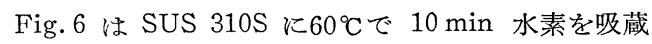
せしめた場合のチャートであるが，水素化物相からの peak は回折強度が非常に強い. $\mathrm{Y}_{1}$ 相はオーステナイ トの peak よりも大きくブロードである.これは水素 化物が多量に生成していることを示している.

Fig. 7 に示すのは $\mathrm{Ni}$ 量がさらに多い $\mathrm{Fe}-32 \% \mathrm{Ni}$ 合金に水素を $10 \mathrm{hr}$ 吸蔵せしめたときの全角チャー トである.この場合もステンレスと同様にY相が生成 するが， $\varepsilon^{\prime}$ 相は観察されなかった. Y相からの回折強 度が非常に強いのは吸蔵時間が長いためとも考えられ るが， $\mathrm{Ni}$ 量に原因すると考觉るべきであろら． $\mathrm{Y}_{1}$ 相, $\mathrm{Y}_{2}$ 相の格子定数は $3.655 \AA$ と $3.633 \AA$ となった.

このように水素化物の生成には合金中の $\mathrm{Ni}$ 量と, 吸蔵される水素量とが密接に関連していると考えられ る.つまり $\mathrm{Ni}$ 量の多い鋼種ほど, また吸蔵水素量が 多いほど生成量は多く，とくにY相が顕著となる。こ のことから不安定形よりも準安定形，安定形オーステ

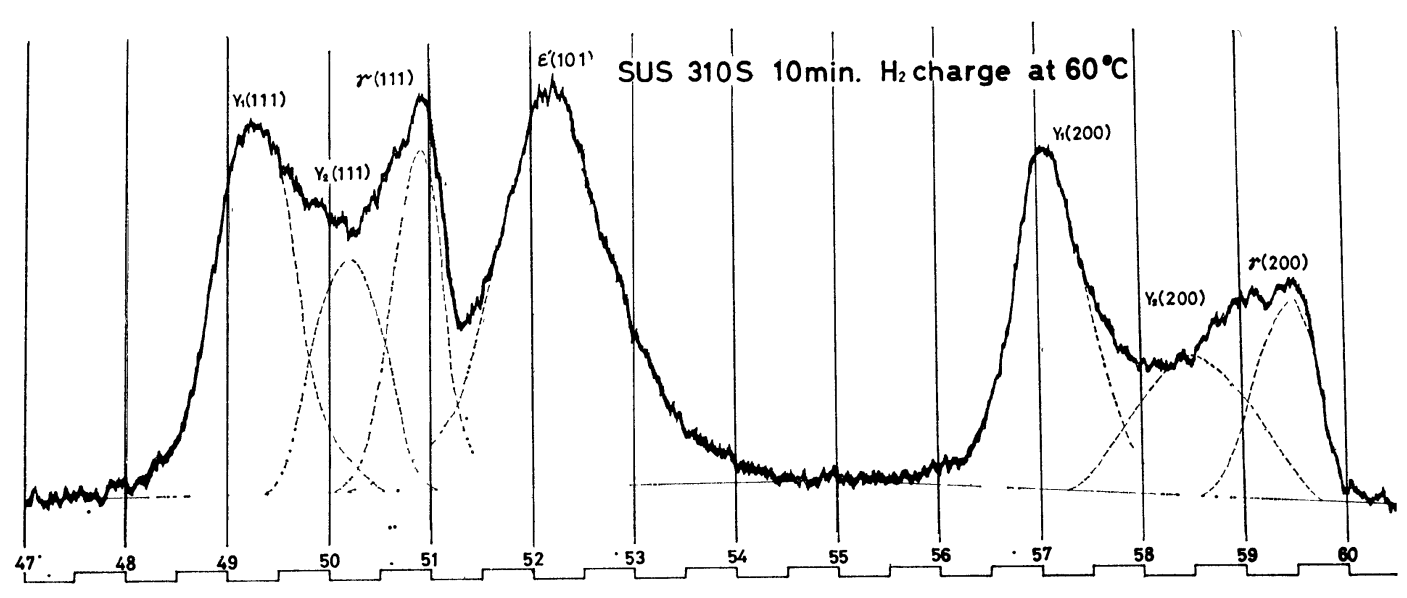

$2 \theta \operatorname{deg}(\operatorname{CoK} \alpha)$

Fig. 6. An X-ray diffraction pattern. Hydride phases produced by cathodic charging at $60^{\circ} \mathrm{C}$. (SUS $310 \mathrm{~S}$ )

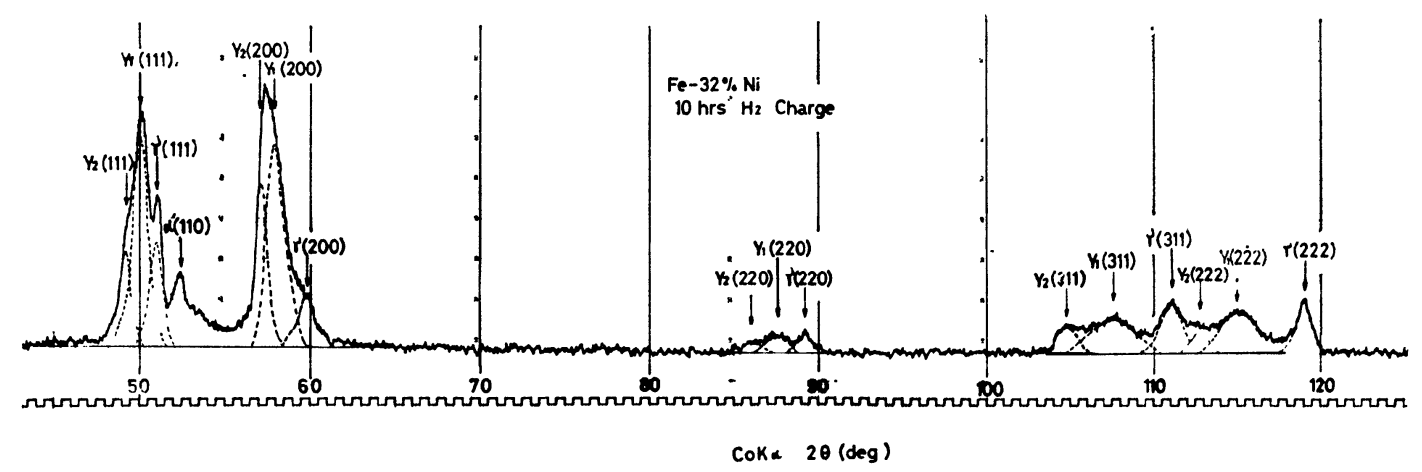

Fig. 7. An X-ray diffraction pattern. Effect of $10 \mathrm{hr}$ hydrogen charge at room temperature. $(\mathrm{Fe}-32 \% \mathrm{Ni})$ 
ナイトの鋼種の方が水素化物を形成し易いと思わ机る。 水素化物相は不安定相であって，水素量によって格 子定数が変化することを Fig. 8 に示す. これはSUS 310S の吸蔵過程に拈ける peak 位置の変化を, Y 相 が最も顕著に現れる（200）面について観察したもので ある. 水素吸蔵 $30 \mathrm{~min}$ ではY相は一つであり $2 \theta=$ $58.6^{\circ}$ にあるが， $60 \mathrm{~min}$ では $\mathrm{Y}_{1}$ 相と $\mathrm{Y}_{2}$ 相に分離 している. 以後 $Y_{2}$ 相は回折位置をほとんど変化させ ないが， $\mathrm{Y}_{1}$ 相はさらに低角度側へシフトする. しか し $2 \theta=57^{\circ}$ 付近までシフトするとほぼ停止して動か ない・これは吸蔵される水素量に飽和点があるためと 考えられる.このときオーステナイトの peak はY相 の生成と共に peak 高さが減少し, 若干低角度側へシ フトしている.このことは水素化物相の生成ばかりで なく，母相格子内にも水素原子が侵入していることを 示している.

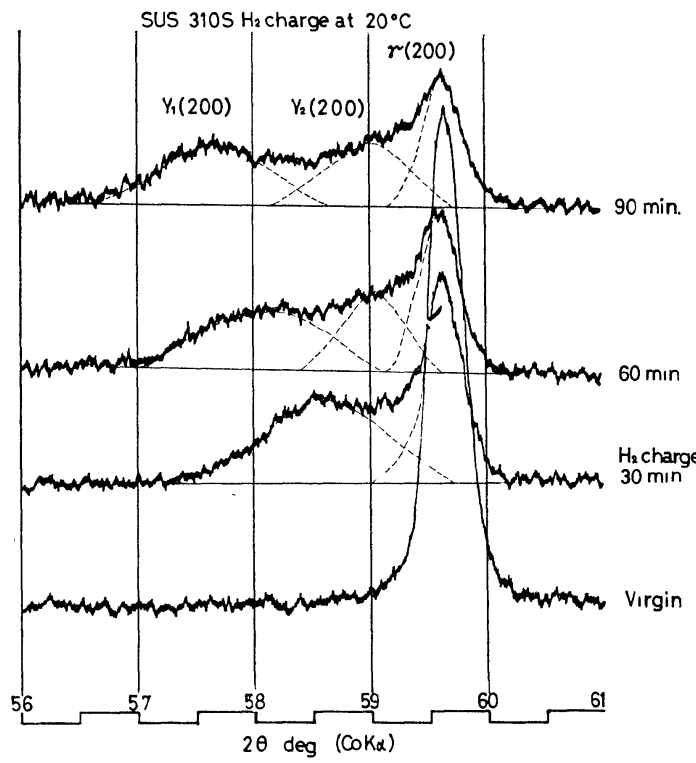

Fig. 8. Change of peak position of hydride phase by cathodic charging at $20^{\circ} \mathrm{C}$. (SUS $310 \mathrm{~S}$ )

水素化物相は単に水素吸蔵時間が増加すれば多く生 成するというものではない. 生成量はオーステナイト の安定性と多分に関係があることは前にも述べた. 水 素化物の生成が母相に与学る影響などについて以下に 述べる.

\section{$3 \cdot 2$ 水素化物相亡変態相の関係}

Fig. 2 に示したように吸蔵時間の増加と共に $\varepsilon^{\prime}$ 相 の peak は顕著となり低角度側にシフトする.さらに 吸蔵を続けると peak はブロートとなって $2 \theta=52.3^{\circ}$ に新しい peak が分離してくる.これは $\alpha^{\prime}$ 、マルテン サイト (110) 面からの peak が重疊して現れた結果 である. $3 \mathrm{hr}$ 吸蔵では $\alpha^{\prime}$ 相の peak はさらに増大
し， $\varepsilon^{\prime}$ 相 $(10 \cdot 1)$ 面からの peak はブロードになりな がら高角度側ヘシフトする.ここで注目されるのは $\alpha^{\prime}$ 相の分離が始むるとY相が消隇することである。すた $\varepsilon^{\prime}$ 相の peak がブロードになるのは $\varepsilon^{\prime}$ 水素化物相と とマルテンサイト相の peak が重畳しているからであ ると思われる．これについては後の昇温時効のところ で明らかにする，以上の結果から吸蔵による変態相生 成の順序は

$$
\gamma \rightarrow \text { hydride }\left(\varepsilon^{\prime}+Y\right) \rightarrow \alpha^{\prime}{ }_{H} \rightarrow \varepsilon_{H}+\alpha^{\prime}{ }_{H}
$$

であると思われる. ここで $\alpha^{\prime}{ }_{H}, \varepsilon_{H}$ は水素誘起マル テンサイトの意味である.（以下同様）

\section{$3 \cdot 3$ 室温時効過程における各相の変化}

Fig. 9 は SUS 304 について $20^{\circ} \mathrm{Cで} 15 \mathrm{~min}$ 水素 吸蔵を行った後, 室温下で時効させたときのプロファ イルの変化である. $\varepsilon^{\prime}$ 相 $(10 \cdot 1)$ 面からの peak は時 效時間の増加と共に高角度側ヘシフトし，ブロードに なっていく. シフトの原因は水素原子の拡散による格 子定数の変化であり，ブロードとなるのは $\varepsilon_{H}$ マルテ ンサイト（10・1）面からの peak が重畳するためでめ ると考えられる. $\varepsilon^{\prime}$ の peak のシフトとブロードにつ いで, $45 \mathrm{~min}$ 時効した頃から $2 \theta=52.3^{\circ}$ に $\alpha_{H}^{\prime}$ マ ルテンサイト (110) 面の peak が現れる. このよう

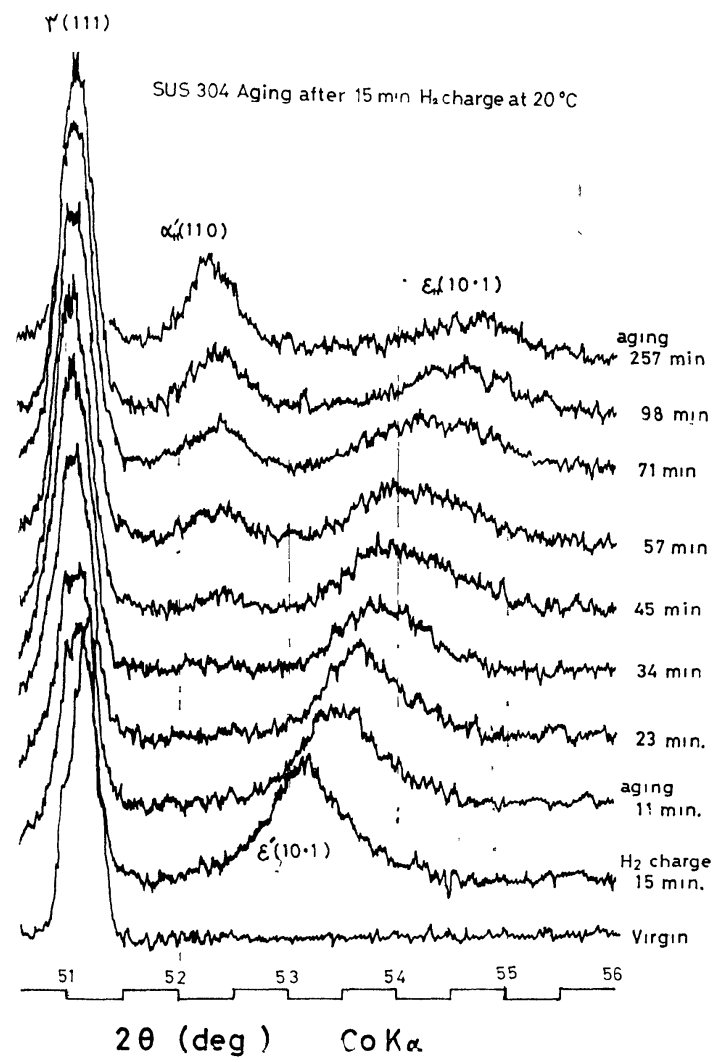

Fig. 9. X-ray diffraction patterns. Effect of aging time after $15 \mathrm{~min}$ hydrogen charge. (SUS 304) 
に水素化物相は室温下で不安定相であり，吸蔵過程と 同様の変態が誘起される.このときの変態順序は $\gamma \rightarrow$ hydride $\left(\varepsilon^{\prime}+Y\right) \rightarrow \varepsilon_{H} \rightarrow \varepsilon_{H}+\alpha^{\prime}{ }_{H}$ であると思われる.

\section{$3 \cdot 4$ 低温保持および昇温過程での各相の挙動}

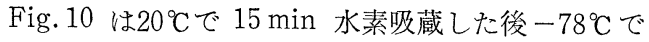
一定時間保持したときのプロファイルである.ここで わかることは， $\varepsilon^{\prime}(10 \cdot 1)$ 面からの peak は $2 \mathrm{hr}$ 保 持した場合でも, 回折位置と強度に変化がみられない ことである.つまり低温では水素化物相は安定である といえる. その後室温中で $15 \mathrm{hr}$ 保持したときのプ ロファイルを一番上に示すが，変態相が誘起されてい

る.すなわら水素化物相が変化しなければ変態相も誘 起されないといらことである.

つぎに $60^{\circ} \mathrm{C}$ にて $10 \mathrm{~min}$ ，水素吸蔵後 $-78^{\circ} \mathrm{C}$ に冷却 し，その後徐々に昇温時効させたときのプロファイル の変化を Fig. 11 に示す. 吸蔵直後ではオーステナイ トの peak は強度が著しく低下して拈り, 低角側に大 きく広がった形になっている. $2 \theta=48.7^{\circ}$ と $56.8^{\circ}$ に $\mathrm{Y}_{1}$ 相の peak がはっきりと現れて和り，多量の水素. 化物相が生成していることを示している， $\varepsilon^{\prime}(10 \cdot 1)$

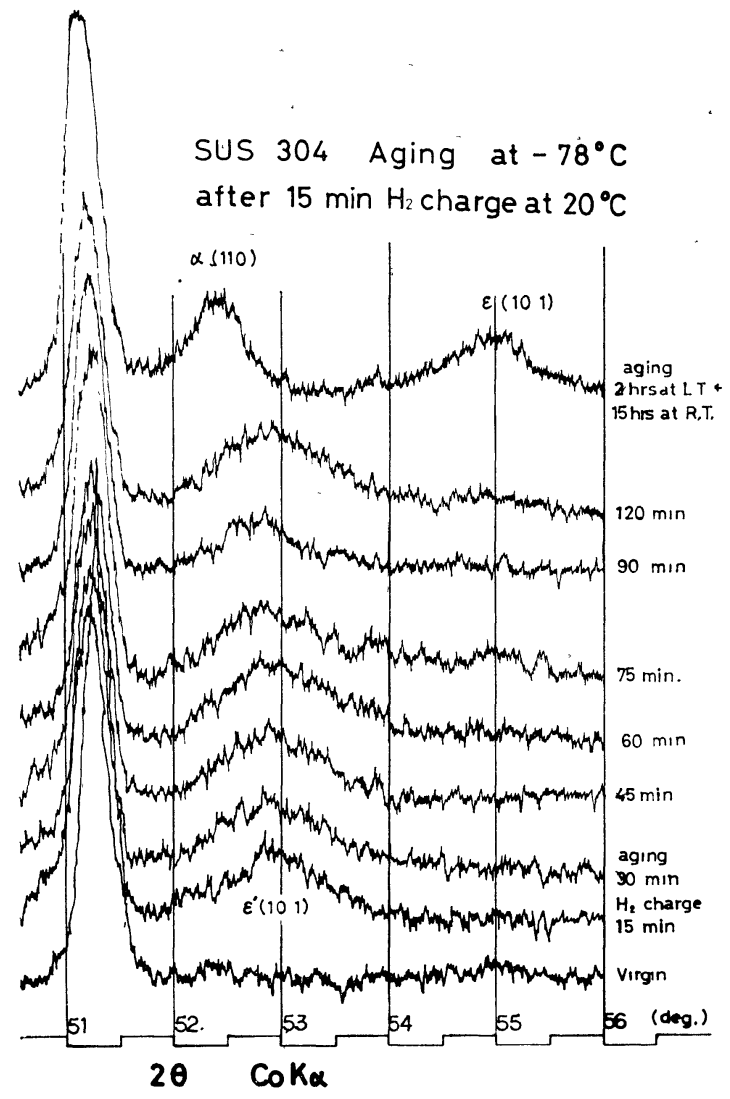

Fig. 10. Effect of aging temperature for hydrogen induced transformation. Aging at $-78^{\circ} \mathrm{C}$ after 15 min hydrogen charge. (SUS 304)

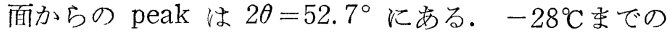
昇温過程においては $\varepsilon^{\prime}$ 相, Y相共に安定で変化が文 られない。さらに昇温すると， $\varepsilon^{\prime}$ 相およびY相のpeak は高角度側ヘシフトし始める. そして $\varepsilon^{\prime}$ 相の peak は 対称性を失い $\alpha^{\prime}{ }_{H}$ マルテンサイト (110) 面からの peak が重畺してくる. $\alpha^{\prime}{ }_{H}$ 相の peak の成長につれ て $2 \theta=54.7^{\circ}$ 付近に $\varepsilon_{H}$ マルテンサイト $(10 \cdot 1)$ 面 からの peak が現れる. また $\varepsilon_{H}$ 相の誘起と同じ頃 $\mathrm{Y}_{1}$ 相の peak は消滅している. さらに変態相が生成し水 素化物相が消隇するとき，オーステナイト母相からの peak は低角度側へわずかであるがシフトしており， 格子が膨張したことを示している. これは分解した水 素化物中の水素原子が母相の格子内に拡散したためと 考えられる.この場合の変態相の生成順序は

$$
\gamma \rightarrow \text { hydride }\left(\varepsilon^{\prime}+Y\right) \rightarrow \alpha^{\prime}{ }_{H} \rightarrow \varepsilon_{H}
$$

であると考えられる，この順序は吸蔵過程の場合と同 じである，吸蔵過程においては変態は鋼中の水素濃度

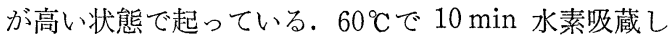
た場合では水素化物相の生成が顕著であり，水素濃度 が非常に高い状態であると考えられることから，変態 相の生成順序が同じであると思われる。

Fig. 12 は Fig. 11 のプロファイルの一部を書き抜 いたものであるが, $\alpha^{\prime}{ }_{H}$ 相 (110), $\dot{\varepsilon}^{\prime}$ 相 $(10 \cdot 1), \varepsilon_{H}$ 相 $(10 \cdot 1)$ 各面からの peak がはっきり区別できるこ とを示している．これにより吸蔵直後に生成する $\varepsilon^{\prime}$ 相が，従来報告されてきたようなマルテンサイトでは なくて, 水素化物相であり, 時効過程によりマルテン サイトが生成することが明らかになった。吸蔵過程に おいて $\varepsilon^{\prime}$ 相の peakがブロードになるのも， $\varepsilon^{\prime}$ 相と $\varepsilon_{H}$ 相の peak が重畳するためであることが明らかに なった。

\section{4 結 論}

以上の実験結果より次のことが明らかになった。

(1) オーステナイト系ステンレス鋼に陰極電解法に よって水素を吸蔵せしめると，化学組成が ( Fe, $\mathrm{Ni}$, Cr) ${ }_{x} \mathrm{H}_{y}$ と考学られる h.c. p. $\varepsilon^{\prime}$ 相, 特よび f.c. c. Y 相の二種類の水素化物相 (Hydride) が生成する.さ らに変態相である b. c. c. $\alpha^{\prime}{ }_{H}$ 相および h. c. p. $\varepsilon_{H}$ 相が誘起される。

（2）水素化物相は鋼中の $\mathrm{Ni}$ 量が多いほど，また吸 蔵温度が高いほど生成が顕著である.この相は低温で は安定な相であるが，温度上昇によって不安定となり 格子定数が変化する. さらに変態相が誘起されると水 素化物相は分解消隇する。

（3）SUS 304 の場合, 吸蔵過程での変態相の生成 順序は

$$
\gamma \rightarrow \text { hydride }\left(\varepsilon^{\prime}+Y\right) \rightarrow \alpha^{\prime}{ }_{H} \rightarrow \varepsilon_{H}
$$

であり, 時効過程では 
SUS 304 Aging at low temp. after $10 \mathrm{~min}$. $\mathrm{H}_{2}$ charge at $60^{\circ} \mathrm{C}$

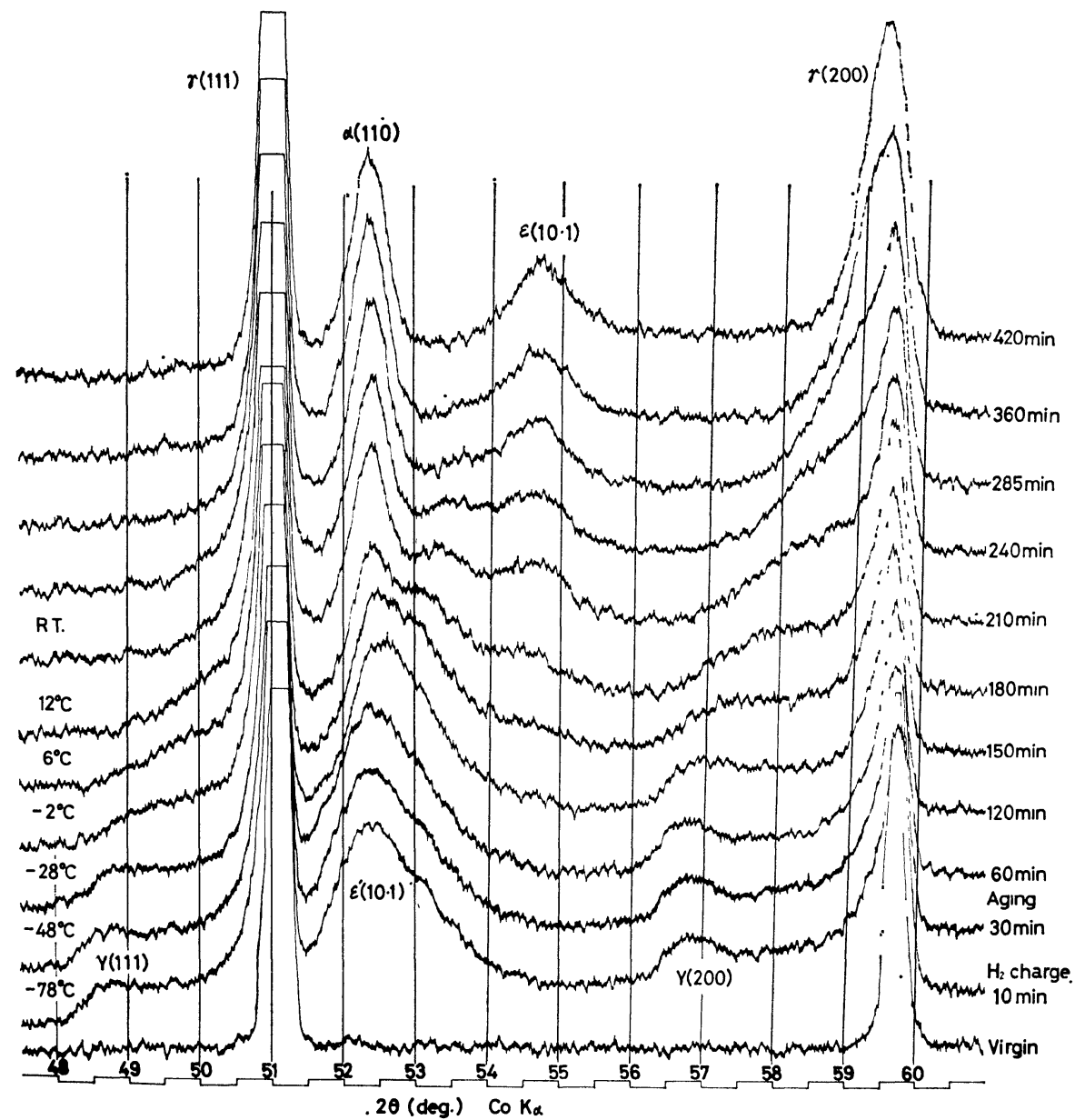

Fig. 11. Effect of aging time at increasing temperature gradually from $-78^{\circ} \mathrm{C}$ to room temperature after $10 \mathrm{~min}$ hydrogen charge at $60^{\circ} \mathrm{C}$. (SUS 304)

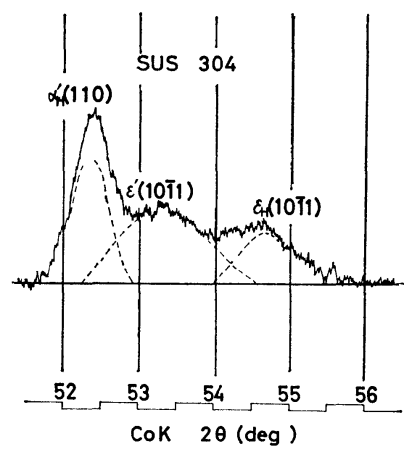

Fig. 12. Distinction between $\varepsilon^{\prime}$ and $\left(\varepsilon_{H}+\alpha^{\prime}{ }_{H}\right)$ on $\mathrm{X}$-ray diffraction pattern.

$$
r \rightarrow \text { hydride }\left(\varepsilon^{\prime}+Y\right) \rightarrow \varepsilon_{H} \rightarrow \alpha^{\prime}{ }_{H}
$$

である.また高温吸蔵を行って低温から昇温時効を行

うと, 吸蔵過程と同様の変態順序で変態相が生成した。 （昭和 51 年 7 月 10 日 第13回材料強度に関するシンポジウムにて講演）

\section{参 考 文 献}

1）蒲地一義, 宮田節夫, 衛藤正美, 日本金属学会誌, 33 , 824 (1969).

2）蒲地一義, 峠 睦, 防食技術, 24, 641 (1975).

3) Vaughan, D. A., D. I. Phalen, C.L. Peterson, and W. K. Boyd, Corrosion, 19, 315 (1963).

4) Holtzworth, M.L., and M.R. Louthan, Jr., Corrosion, 24, 110 (1968).

5) Okada, H., Y. Hosoi, and S. Abe, Corrosion, 26, 183 (1970).

6) 大谷南海男, 浅野 滋, 藤島芳雄, 山桝義和, 日本金属 学会誌, 37, 746 (1973). 